\title{
Malignant Mediastinal Soft Tissue Neoplasm
}

National Cancer Institute

\section{Source}

National Cancer Institute. Malignant Mediastinal Soft Tissue Neoplasm. NCI Thesaurus.

Code C6642.

A malignant neoplasm that arises from the soft tissues of the mediastinum. 